\title{
Development and Physical Characterization of Meclizine Hydrochloride Solid Dispersions by using Polyethylene Glycol 8000
}

\author{
Sateesh Kumar Vemula ${ }^{1,2 \star}$ and Radhika Katkum ${ }^{3}$ \\ ${ }^{1}$ College of Medical and Health Sciences, Wollega University, Post Box No: 395, Nekemte, Ethiopia \\ ${ }^{2}$ Department of Pharmaceutics, Chaitanya College of Pharmaceutical Sciences, Hanamkonda-506001, \\ Warangal, Andhra Pradesh, India \\ ${ }^{3}$ Department of Physics, Vaagdevi Group of Colleges, Hanamkonda-506001, Warangal, Andhra Pradesh, \\ India
}

\begin{tabular}{|c|c|}
\hline Abstract & Article Information \\
\hline $\begin{array}{l}\text { Development of the meclizine hydrochloride solid dispersions using polyethylene glycol } \\
8000 \text { is not only to enhance the solubility and dissolution rate but also to produce rapid } \\
\text { onset of action. The objectives of present research are to improve the solubility and } \\
\text { dissolution rate of meclizine hydrochloride using solid dispersion method. In the present } \\
\text { study, the solid dispersions were prepared using solvent evaporation method and } \\
\text { evaluated for different physical parameters such as solubility, drug carrier compatibility and } \\
\text { powder flow properties. From the results of solubility studies, F4 formulation was selected } \\
\text { to prepare the fast dissolving tablets because it showed highest improvement in the } \\
\text { solubility among the all formulations and compared with control tablets (conventional } \\
\text { tablets using pure drug). The percent drug release in } 15 \text { min }\left(Q_{15}\right) \text { and initial dissolution } \\
\text { rate for F4 tablets was } 98.52 \pm 1.34 \%, 6.56 \% / \text { min and these were very much higher } \\
\text { compared to control tablets ( } 32.49 \pm 1.29 \%, 2.17 \% / m i n) \text {. The relative dissolution rate was } \\
\text { found to be } 3.03 \text { and dissolution efficiency was found to be } 54.45 \text { and it is increased by } 3.5 \\
\text { fold with F4 formulation compared to control tablets ( } 16.55) \text {. Hence the formulation of } \\
\text { polyethylene glycol } 8000 \text { solid dispersions is a suitable method to enhance the solubility } \\
\text { and dissolution rate of meclizine hydrochloride. Further research warranted to study the } \\
\text { efficacy of the developed formulations has to be assessed by pharmacokinetic studies. } \\
\text { Copyright@2014 STAR Journal. All Rights Reserved. }\end{array}$ & $\begin{array}{l}\text { Article History: } \\
\text { Received : 30-12-2013 } \\
\text { Revised : 10-03-2014 } \\
\text { Accepted : 24-03-2014 } \\
\text { Keywords: } \\
\text { Dissolution efficiency } \\
\text { Initial dissolution rate } \\
\text { Relative dissolution rate } \\
\text { Solvent evaporation } \\
\text { Solubility studies } \\
{ }^{*} \text { Corresponding Author: } \\
\text { Sateesh Kumar Vemula } \\
\text { E-mail: } \\
\text { vemulasatish15@gmail.com }\end{array}$ \\
\hline
\end{tabular}

\section{INTRODUCTION}

Now days, the pharmaceutical formulation scientists are extensively paying the attention on development of oral dosage forms of poor aqueous solubility drugs through various solubility enhancing approaches (Kaushik et al., 2004). Among those, solid dispersions is one of the widely used approaches to of enhance the solubility and dissolution rate of poorly water-soluble drugs (Patil and Gaikwad, 2009). Solid dispersions are defined as molecular dispersions of drugs in a polymer in solid form. Solvent evaporation method and fusion method are widely used to formulate the solid dispersions (Vippagunta et al., 2002).

Meclizine hydrochloride (MCZ) is a first-generation antihistamine of the piperazine class drug. It is acting as $\mathrm{H} 1$ receptor antagonist and practically insoluble in water (Goyani et al., 2012). MCZ is widely used in the treatment of motion sickness, but due to poor water solubility delayed the onset of action. To overcome this problem, this drug is selected for the present study. Nimisha et al. (2012) formulated the MCZ mouth dissolving tablets to enhance the dissolution rate as well as the patient compliance. In this study, mouth dissolving tablets were prepared by superdisintegrant addition and sublimation technique and they showed sufficient mechanical integrity to assist patients of any age group for easy administration. George and Vasudevan (2012) were prepared the cyclodextrin-MCZ inclusion complexes to investigate the effect of 2-hydroxypropyl- $\beta$-cyclodextrins and $\beta$-cyclodextrins on MCZ aqueous solubility and dissolution. The phase solubility profile indicated that the solubility of MCZ was significantly increased in the presence of both 2-hydroxypropyl- $\beta$-cyclodextrin and $\beta$ cyclodextrin and their in vitro dissolution study were showed that, the solubility and dissolution rate of MCZ were significantly improved by complexation with 2hydroxypropyl- $\beta$-cyclodextrin. Vangala et al. (2014) developed and prepared the MCZ sublimated fast dissolving tablets to improve the dissolution rate and the tablets containing $10 \% \mathrm{w} / \mathrm{w}$ camphor as sublimating agent showed rapid drug release when compared to other formulations. Gupta et al. (2011) developed the MCZ 


\section{Sateesh Kumar and Radhika}

rapidly dissolving oral films to enhance the dissolution rate and to mask the bitter taste. In this study, the fast dissolving films with suitable appearance, mechanical strength and disintegration time were obtained using Methocel E-5 as a primary film former. MCZ, a poorly water soluble and bitter drug could be successfully incorporated in the fast dissolving films with the help of solubilizers such as $\beta$-Cyclodextrine and polyethylene glycol 400 . The perusal of the literature showed that there is no literature available on the use of less polymer concentration for the preparation of fast dissolving tablets. Hence, the present research has been undertaken to formulate the MCZ fast dissolving tablets of using solid dispersion method to enhance the solubility and dissolution rate.

\section{MATERIALS AND METHODS}

\section{Materials}

Meclizine hydrochloride was gift sample from Symed labs Ltd, India. Polyethylene Glycol 8000 and all other reagents used were of analytical grade and obtained from S.D. Fine Chemicals, Mumbai, India.

\section{Preparation of Solid Dispersions}

In this study, MCZ solid dispersions were prepared by the solvent evaporation method using PEG 8000 as carrier (Table 1). Accurately weighed amount of drug and carriers in various ratios dissolved in ethanol in a round bottom flask and the solvent was evaporated at $40^{\circ} \mathrm{C}$ temperature. Then it was stored in a vacuum oven at room temperature for $48 \mathrm{~h}$ to remove the residual solvent. The dried solid dispersions were grinded, passed through sieve \# 60 and stored in desiccators until use (Chaitanya et al., 2014).

Table 1: Formulation of MCZ-PEG8000 solid dispersions.

\begin{tabular}{ccc}
\hline $\begin{array}{c}\text { Formulation } \\
\text { Code }\end{array}$ & MCZ HCI & $\begin{array}{c}\text { MCZ:PEG 8000 } \\
\text { ratio }\end{array}$ \\
\hline F1 & 25 & $1: 0.5$ \\
F2 & 25 & $1: 1$ \\
F3 & 25 & $1: 2$ \\
F4 & 25 & $1: 4$ \\
F5 & 25 & $1: 6$ \\
F6 & 25 & $1: 8$ \\
\hline
\end{tabular}

\section{Solubility Studies}

The prepared solid dispersions were evaluated for solubility studies in $0.1 \mathrm{~N} \mathrm{HCl}$, distilled water and $7.4 \mathrm{pH}$ phosphate buffers. An excess amount of MCZ solid dispersion was weighed and transferred into conical flasks which contain $10 \mathrm{ml}$ of media. The content in conical flask were sonicated for $2 \mathrm{~h}$ at room temperature, there after the samples were placed on a shaker, agitated at room temperature for $48 \mathrm{~h}$. Subsequently, the suspensions were filtered through a Whatman filter paper. The filtrate was suitably diluted and analyzed spectrophotometrically at a wavelength of $232 \mathrm{~nm}$ using a double beam UVVisible spectrophotometer (Vaskula et al., 2012).

\section{Drug-carrier Interaction Studies}

The thermograms were recorded for drug, carrier, and physical mixture using differential scanning calorimeter (Shimadzu, Japan). About 2-4 mg sample in an open aluminium standard pan was heated at a scanning rate of $5^{0} \mathrm{C} / \mathrm{min}$ from a temperature 0 to $450{ }^{\circ} \mathrm{C}$ under a nitrogen gas flow (Neduri et al., 2013).
Sci. Technol. Arts Res. J., Jan-March 2014, 3(1): 48-52

\section{Evaluation of Flow Properties}

The flow properties were determined by calculating the angle of repose and Carr's index. Powder mixtures of different formulations were evaluated for angle of repose, bulk density, tapped density and Carr's index. The fixed funnel method was employed to measure the angle of repose $(\theta)$ and it was calculated using the following formula:

$$
\operatorname{Tan} \theta=h / r
$$

In which, $\theta$ is the angle of repose, $\mathrm{h}$ is the height of the cone and $r$ is radius of the cone base. To measure the angle of repose, a funnel was fixed to a stand so that the lower tip of funnel was $2.5 \mathrm{~cm}$ above the surface. A graph paper was placed on a flat surface. The powder blend was allowed to fall freely on the graph paper through the funnel $(6.8 \mathrm{~cm}$ diameter), till the tip (8 $\mathrm{mm}$ diameter) of heap formed just touches the funnel. The radius of heap was noted and from this angle of repose was determined. The bulk density $\left(\rho_{b}\right)$ of a powder is determined by measuring the volume of a known mass of powder sample that may have been passed through a screen, into a $50 \mathrm{ml}$ graduated cylinder. Tapped density $\left(\rho_{\text {tap }}\right)$ of powder samples were determined by a tap density apparatus. The apparatus was set for 500 tapings for $5 \mathrm{~min}$ at stroke height $20 \mathrm{~mm}$ at the rate of 100 strokes/min (Veerareddy and Vemula, 2012). The Carr's Index is a measure of the propensity of a powder to be compressed and it is calculated using the following formula:

$$
\text { Carr's Index }=\left[\left(\rho_{\text {tap }}-\rho_{b}\right) / \rho_{\text {tap }}\right] / \times 100 \text {. }
$$

\section{Preparation of Fast Dissolving Tablets}

Formulation F4 was selected to prepare the MCZ fast dissolving tablets (FDTs) based on the results of dissolution and solubility studies (Table 2). The FDTs were prepared by direct compression method. The solid dispersion powder equivalent to $25 \mathrm{mg}$ of $\mathrm{MCZ}$, crosspovidone and other excipients were passed through a mesh no 60. The powdered solid dispersion was mixed with proper portion of crosspovidone. Then excipients other than glidant and lubricant were added and mixed in a poly bag for 5-10 min. The obtained blend was lubricated with talc and magnesium stearate for another 5 min and the resultant mixture was directly compressed into tablets using rotary tabletting machine (Vemula et al., 2010).

Table 2: Composition of MCZ tablets using selected solid dispersions.

\begin{tabular}{lll}
\hline \multirow{2}{*}{ Formulation Code } & \multicolumn{2}{c}{ Ingredients in $\mathbf{~ m g}$} \\
\cline { 2 - 3 } & F4 & Control \\
\hline MCZ Solid dispersion equivalent & 125 & - \\
to 50 mg MCZ & - & 25 \\
Pure MCZ & 10 & 10 \\
Crosspovidone & 59 & 159 \\
Spry-dried lactose & 2 & 2 \\
Magnesium stearate & 4 & 4 \\
Talc & 200 & 200 \\
Total Tablet weight &
\end{tabular}

\section{Evaluation of Physical Parameters}

The prepared tablets were studied for their physical properties like weight variation, hardness, friability and drug content unifrmity. For estimating weight variation, 20 tablets of each formulation were weighed using an 


\section{Sateesh Kumar and Radhika}

electronic weighing balance (AW 120, Shimadzu Corporation, Japan). The hardness of six tablets was measured using Monsanto tablet hardness tester. Friability was determined on ten tablets in a Roche friabilator (Electrolab, Mumbai, India). For estimation of drug content, ten tablets were crushed, and $100 \mathrm{mg}$ of the powder was accurately weighed and transferred to a 100 $\mathrm{ml}$ volumetric flask. Initially about $50 \mathrm{ml}$ of $7.4 \mathrm{pH}$ phosphate buffer was added to the volumetric flask and allowed to stand for 6-8 $\mathrm{h}$ with intermittent shaking to ensure complete solubility of the drug. Then the volume was made up to $100 \mathrm{ml}$ with buffer, filtered and analyzed for MCZ content at $232 \mathrm{~nm}$. In vitro disintegration time of FDT's was estimated using the Gohel procedure. Briefly, $10 \mathrm{ml}$ of water at room temperature was taken in a petridish of $10 \mathrm{~cm}$ in diameter. The tablet was then carefully placed in the centre of petridish and the time required for the tablet to completely disintegrate into fine particles was noted (Gohel et al., 2004).

\section{In vitro Dissolution Study}

The MCZ release from the prepared FDTs was carried out using USP XXIV Type II dissolution apparatus (Electro lab, TDT-08L) at a rotation speed of $50 \mathrm{rpm}$, and a temperature of $37.0 \pm 0.5^{\circ} \mathrm{C}$. The drug release studies were carried out in $7.4 \mathrm{pH}$ phosphate buffer. An aliquot of $5 \mathrm{ml}$ was collected at predetermined time intervals and replaced with fresh dissolution medium. The samples were filtered, by passing through $0.45 \mu \mathrm{m}$ membrane filters (Millipore, USA) \& analyzed spectrophotometrically at $232 \mathrm{~nm}$. Then a graph was plotted using cumulative percent drug release as a function of time and percent drug release in $15 \mathrm{~min}$ (Q15) was calculated. Initial dissolution rate (IDR) was calculated as percentage dissolved of drug over the first $15 \mathrm{~min}$ per min. Dissolution efficiency (DE) was calculated from the area under the dissolution curve at time $t$ (measured using the trapezoidal rule) and expressed as a percentage of the area of the rectangle described by $100 \%$ dissolution in the same time. Relative dissolution rate (RDR) is the ratio between amount of drug dissolved from best formulation and from the control formulation at $15 \mathrm{~min}$ (vemula et al., 2011).

\section{Stability Studies}

The stability studies of prepared tablets were planned on the $\mathrm{F} 4$ tablets according to $\mathrm{ICH}$ guidelines. The packed samples $(n=3)$ were stored in the stability chamber maintained at $40 \pm 2{ }^{\circ} \mathrm{C}$ and $75 \pm 5 \% \mathrm{RH}$ for six months. After six months of storage, the samples were collected and analyzed for assay and in vitro dissolution rate. Then the data was analyzed using paired t-test to test the significant variation at 0.05 level of significance (LS). Then the similarity index (F2) was calculated between dissolution rates of tablets before and after storage to prove the stability of tablets (Vemula and Veerareddy, 2013; Vemula and Bontha, 2013).

\section{RESULTS AND DISCUSSION}

\section{Solubility Studies of MCZ Solid Dispersions}

The aqueous solubility of the solid dispersion formulations of different carriers was determined in different media i.e., $0.1 \mathrm{~N} \mathrm{HCl}$, distilled water and phosphate buffer $\mathrm{pH}$ 7.4. From the solubility studies of the prepared solid dispersions in different media, it was found that as the increase in $\mathrm{pH}$ of the media increased the solubility i.e. MCZ showed superior solubility in $7.4 \mathrm{pH}$ phosphate buffer when compared others. The solubility
Sci. Technol. Arts Res. J., Jan-March 2014, 3(1): 48-52

data of different formulations using different carriers showed in Table 3. From the results given in above tables, solid dispersions with PEG 8000 showed significant improvement in solubility with increasing PEG ratio up to $1: 4$ ratios, but after no significant improvement in solubility by increasing the ratio of carrier. From all the solid dispersions, formulation F4 showed highest solubility in $7.4 \mathrm{pH}$ phosphate buffer. Similar type of results observed in Patel et al., 2011 study i.e., the solubility of flurbiprofen was measured in four different media and the results showed that the solubility of the flurbiprofen was highest at $\mathrm{pH} 7.2$, and decreased as the $\mathrm{pH}$ decreases.

Table 3: Solubility studies of MCZ-PEG 8000 solid dispersions (Mean $\pm S D, n=3$ )

\begin{tabular}{llll}
\hline \multirow{2}{*}{$\begin{array}{l}\text { Formulation } \\
\text { Code }\end{array}$} & \multicolumn{4}{l}{ MCZ solubility in $\mathbf{~ m g} / \mathbf{m l}$} \\
\cline { 2 - 4 } & $\mathbf{0 . 1} \mathbf{~ N ~ H C l}$ & $\begin{array}{l}\text { Distilled } \\
\text { Water }\end{array}$ & $\begin{array}{l}\mathbf{7 . 4} \\
\text { Buffer }\end{array}$ \\
\hline Pure FLB & $0.342 \pm 0.21$ & $0.961 \pm 0.18$ & $0.975 \pm 0.23$ \\
F1 & $0.409 \pm 0.19$ & $1.127 \pm 0.15$ & $1.424 \pm 0.46$ \\
F2 & $0.487 \pm 0.27$ & $1.292 \pm 0.28$ & $1.486 \pm 0.12$ \\
F3 & $0.518 \pm 0.36$ & $1.343 \pm 0.56$ & $1.579 \pm 0.28$ \\
F4 & $0.542 \pm 0.13$ & $1.471 \pm 0.48$ & $1.663 \pm 0.53$ \\
F5 & $0.604 \pm 0.32$ & $1.481 \pm 0.75$ & $1.669 \pm 0.37$ \\
F6 & $0.613 \pm 0.18$ & $1.489 \pm 0.51$ & $1.672 \pm 0.72$ \\
\hline
\end{tabular}

\section{Drug-carrier Interaction Studies}

The thermograms of the MCZ, PEG 8000, physical mixture of MCZ with PEG 8000 were shown in Figure 1. The DSC thermograms of MCZ exhibited a sharp endothermal peak around $206.66^{\circ} \mathrm{C}$ corresponding to melting point. The DSC thermogram of PEG 8000 exhibited a broad endothermal peak around $69.5^{\circ} \mathrm{C}$ corresponding to its melting point. The thermogram of physical mixture with PEG 8000 showed a short endothermal peak of drug at $206{ }^{\circ} \mathrm{C}$ indicating that there were no interactions between drug and carrier.

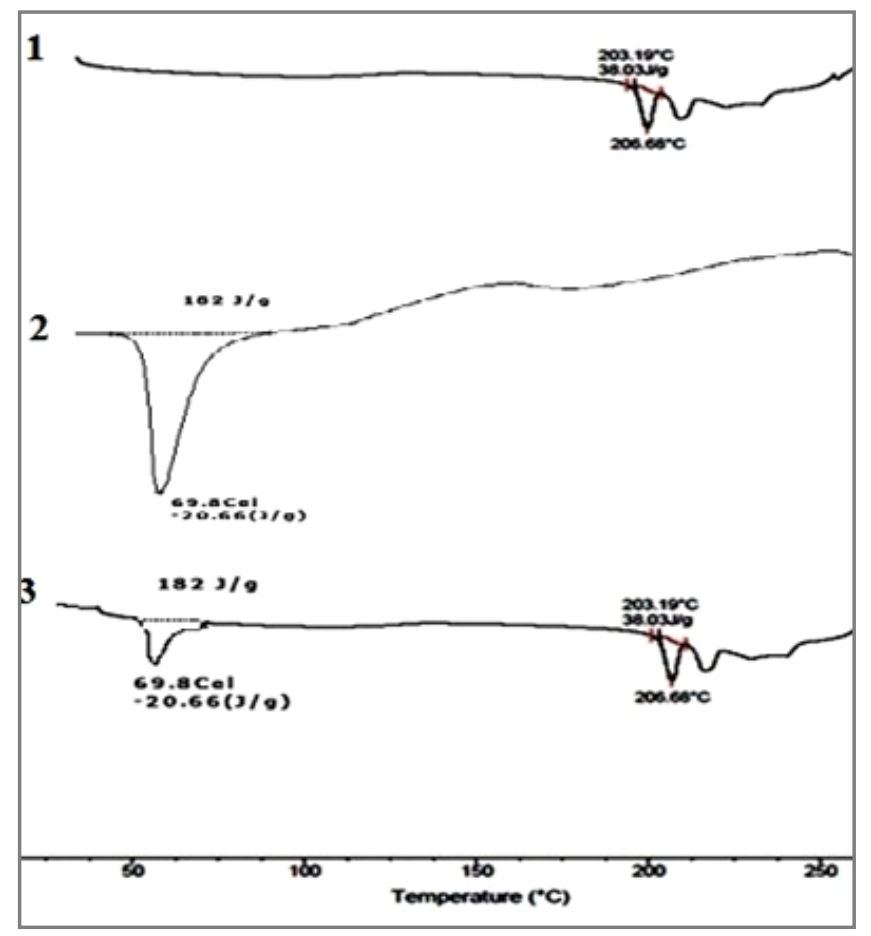

Figure 1: DSC thermograms of 1) MCZ 2) PEG 8000 3) F4 physical mixture. 


\section{Sateesh Kumar and Radhika}

\section{Evaluation of Flow Properties}

The powder mixture for tablets were characterized with respect to angle of repose, bulk density, tapped density and Carr's index (Table 4). Angle of repose was less than $35^{\circ}$ and Carr's index values were less than 21 for the powder mixture of all the batches indicating good to fair flowability (Staniforth and Aulton, 2007).

\section{Evaluation of Physical Parameters}

Based on the solubility studies, the better solid dispersions were converted into tablets. Table 5 showed all the physical parameters determined for MCZ tablets. In weight variation test, the pharmacopoeial limits for the tablets of not more than $5 \%$ of the average weight. The tablet hardness and friability were found to be around 3.0 $\mathrm{kg} / \mathrm{cm}^{2}$ and $0.38 \%$, demonstrating the integrity and strength of tablets. The tablets assay was found to contain $98.76 \pm 1.43 \%$. From the disintegration test, the prepared tablets were disintegrated rapidly and it was found to be around $120 \mathrm{sec}$.

\section{In vitro Dissolution Study}

From the in vitro dissolution studies, tablets made from $1: 4$ ratio solid dispersion (F4) showed fast dissolution $(98.52 \pm 1.34 \%$ in $15 \mathrm{~min})$ than other formulations and improved significantly when compared to control tablet (Figure 2). From the in vitro dissolution studies, F4 FDTs showed significant increase in dissolution rate when compared to control tablets with pure drug. In the following reported study by Singh et al., similar type of solubility enhancement was observed with PEG 6000 solid dispersions (Singh et al., 2011).

The percent drug release in $15 \min \left(Q_{15}\right)$ and initial dissolution rate for formulation $\mathrm{F} 4$ was $98.52 \pm 1.34 \%$, $6.56 \% / \mathrm{min}$. These were very much higher compared to control tablets $(32.49 \pm 1.29 \%, 2.17 \% / \mathrm{min})$. The relative dissolution rate was found to be 3.03 and dissolution efficiency was found to be 54.45 and it is increased by 3.5 fold with F4 formulation compared to control tablets
Sci. Technol. Arts Res. J., Jan-March 2014, 3(1): 48-52

(16.55). Overall increase in the dissolution performance of the optimized formulation was described in terms of dissolution parameters (IDR, DE, RDR) and when compared with control tablets and all the above parameters were increased in case of F4 formulation (Table 6). Similar type of improvement in IDR, DE, RDR was reported in the study of Vemula et al. (2011).

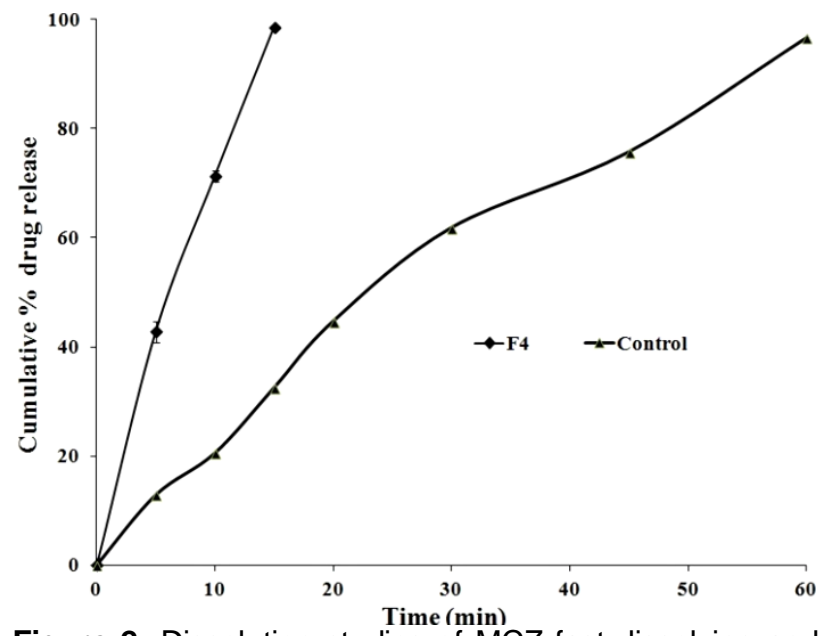

Figure 2: Dissolution studies of $\mathrm{MCZ}$ fast dissolving and control tablets

\section{Stability Studies}

After storage of six months, the formulation F4 was subjected to a drug assay and in vitro dissolution studies (Table 7) and from the statistical analysis there was no significant difference between before and after storage $(P<0.05)$. The similarity index value between dissolution profiles of optimized formulation before and after storage was found to be 85.12 , which is more than 50 indicates similarity between the dissolution profile before and after storage (Vemula and Veerareddy, 2013; Vemula and Bontha, 2013).

Table 4: Evaluation of pre-compression parameters (Mean $\pm S D, n=3$ ).

\begin{tabular}{ccccc}
\hline Formulation & $\begin{array}{c}\text { Angle of Repose } \\
(\mathbf{0})\end{array}$ & $\begin{array}{c}\text { Bulk Density } \\
\left(\mathbf{g m} / \mathbf{c c}^{\mathbf{3}}\right)\end{array}$ & $\begin{array}{c}\text { Tapped Density } \\
\left(\mathbf{g m} / \mathbf{c c}^{\mathbf{3}}\right)\end{array}$ & $\begin{array}{c}\text { Carr's Index } \\
(\%)\end{array}$ \\
\hline F4 & $29.15 \pm 1.72$ & 0.345 & 0.407 & 15.23 \\
Control & $27.36 \pm 1.26$ & 0.339 & 0.397 & 14.61 \\
\hline
\end{tabular}

Table 5: Physical properties of MCZ tablets.

\begin{tabular}{|c|c|c|c|c|c|}
\hline Formulation & $\begin{array}{c}\text { Weight variation* } \\
(\mathrm{mg})\end{array}$ & $\begin{array}{c}\text { Hardness } † \\
\left(\mathrm{Kg} / \mathrm{cm}^{2}\right)\end{array}$ & $\begin{array}{c}\text { Friability } \\
(\%)\end{array}$ & $\begin{array}{c}\text { Disintegration time } \\
\text { (sec) }\end{array}$ & $\begin{array}{c}\text { Drug content } \neq \\
(\%)\end{array}$ \\
\hline $\mathrm{F} 4$ & $201.18 \pm 1.72$ & $3.0 \pm 0.23$ & 0.38 & $121 \pm 4$ & $98.76 \pm 1.43$ \\
\hline Control & $201.76 \pm 1.39$ & $3.0 \pm 0.18$ & 0.33 & $118 \pm 4$ & $99.12 \pm 1.38$ \\
\hline
\end{tabular}

Table 6: Dissolution parameters of MCZ F4 and control tablets (Mean \pm SD, $n=3$ ).

\begin{tabular}{ccccc}
\hline Formulation & $\left(\mathbf{Q}_{\mathbf{1 5}}\right)$ & IDR $(\% / \mathbf{m i n})$ & DE & RDR \\
\hline F4 & $98.52 \pm 1.34$ & 6.56 & 54.45 & \multirow{2}{*}{3.03} \\
Control & $32.49 \pm 1.29$ & 2.17 & 16.55 & \\
\hline
\end{tabular}

Table 7: Stability Studies of MCZ F4 tablets (Mean \pm SD, $n=3$ ).

\begin{tabular}{ccccc}
\hline $\begin{array}{c}\text { Time } \\
(\mathbf{m i n})\end{array}$ & $\begin{array}{c}\text { Before } \\
\text { storage }\end{array}$ & $\begin{array}{c}\text { After } \mathbf{6} \text { months } \\
\text { storage }\end{array}$ & $\begin{array}{c}\boldsymbol{t} \text {-test } \\
\text { at } \mathbf{0 . 0 5} \text { LS }\end{array}$ & $\begin{array}{c}\text { Similarity } \\
\text { Factor (F2) }\end{array}$ \\
\hline 0 & $0.00 \pm 0.00$ & $0.00 \pm 0.00$ & & \\
5 & $42.61 \pm 1.37$ & $40.23 \pm 1.45$ & Not Significant & 85.12 \\
10 & $71.34 \pm 1.45$ & $69.75 \pm 1.24$ & & \\
15 & $98.52 \pm 1.34$ & $96.79 \pm 1.19$ & & \\
\hline \% Assay & $\mathbf{9 8 . 7 6} \pm \mathbf{1 . 4 3}$ & $\mathbf{9 7 . 1 4} \pm \mathbf{1 . 2 8}$ & Not Significant & -- \\
\hline
\end{tabular}




\section{Sateesh Kumar and Radhika}

\section{CONCLUSION}

Attempts was made to prepare the solid dispersions using various weight ratios of meclizine hydrochloride and PEG 8000 and evaluated for physiochemical properties. In vitro dissolution rate of solid dispersion tablets was improved significantly when compared to control tablets due to intermolecular interactions between the polymer and drug. From the results of in vitro dissolution study, tablets containing polyethylene glycol 8000 showed almost complete drug release within the $15 \mathrm{~min}$. The percent drug release in $15 \mathrm{~min}\left(Q_{15}\right)$ and initial dissolution rate for formulation $\mathrm{F} 4$ was $98.52 \pm 1.34 \%, 6.56 \% / \mathrm{min}$. These were very much higher compared to control tablets $(32.49 \pm 1.29 \%, 2.17 \% / \mathrm{min})$. The relative dissolution rate was found to be 3.03 and dissolution efficiency was found to be 54.45 and it is increased by 3.5 fold with F4 tablets compared to control tablets (16.55). Thus the development of the PEG solid dispersions can be a promising alternative method to gain the fast dissolution rate.

\section{ACKNOWLEDGEMENT}

The authors acknowledge the Symed labs Ltd, India for gift samples. The authors also thank to Management, Chaitanya College of Pharmacy Education and Research for providing facilities.

\section{REFERENCES}

Chaitanya, P., Jyothi, P., Devadasu, V.R., Venisetty, R.K., Vemula, S.K. (2014). Ezetimibe solid dispersions: formulation, development and in vitro evaluation. American Journal of Advanced Drug Delivery 2(1): 90103.

George, S., Vasudevan, D. (2012). Studies on the preparation, characterization, and solubility of 2 -HP- $\beta$ cyclodextrin-meclizine $\mathrm{HCl}$ inclusion complexes. Journal of Young Pharmacist 4(4): 220-227.

Gohel, M., Patel, M., Amin, A., Agrawal, R., Dave, R., Bariya, N. (2004). Formulation design and optimization of mouth dissolve tablets of nimesulide using vacuum drying technique. AAPS PharmSciTech 5: Article 36.

Goyani, M., Shah, P., Vyas, B., Shah, D. (2012). Formulation and evaluation of orodispersible tablets of meclizine hydrochloride. International Research Journal of Pharmacy 3: 196-199.

Gupta, M.M, Patel, M.G., Kedawat M. (2011). Enhancement of dissolution rate of rapidly dissolving oral film of meclizine hydrochloride by complexation of Meclizine hydrochloride with $\beta$-cyclodextrine. Journal of Applied Pharmaceutical Science 01 (09): 150-153.

Kaushik, D., Dureja, H., Saini, T.R. (2004). Mouth dissolving tablets: a review. Indian Drugs 41: 187-193.

Neduri, K., Bontha, V.K., Vemula, S.K. (2013). Different techniques to enhance the dissolution rate of lovastatin: formulation and evaluation. Asian Journal of Pharmaceutical and Clinical Research 1: 56-60.
Sci. Technol. Arts Res. J., Jan-March 2014, 3(1): 48-52

Nimisha, Pal, P., Srivastava, D. (2012). Formulation and evaluation of meclizine hydro chloride mouth dissolving tablets: An attempt to enhance patient compliance. Indian Journal of Pharmaceutical Science 4 (6): 307-311.

Patel, J.H., Tiwari, P., Patel, J.S. (2011). Solid dispersion based tablets of poorly soluble drug flurbiprofen. American Journal of Pharmtech Research 1(1): 18-24.

Patil, M.P., Gaikwad, N.J. (2009). Preparation and characterization of gliclazide-polyethylene glycol 4000 solid dispersions. Acta Pharma 59: 57-65.

Singh, S.K., Som, S., Shankhwar, U. (2011). Formulation and optimization of solid dispersion of Clopidogrel with PEG 6000. Journal of Applied Pharmaceutical Science 01 (08): 217-226.

Staniforth, J.N., Aulton, M.E. (2007). Powder flow. In, Aulton, M.E. (Eds.), Aulton's pharmaceutics-The design and manufacture of medicines. Churchill Livingstone: Elsevier. pp. 168-179.

Vangala, M., Veerareddy, P.R., Devadasu, V.R., Vemula, S.K. (2014). Meclizine hydro chloride fast dissolving tablets by sublimation method: formulation and evaluation. American Journal of Advanced Drug Delivery 2(2): 133-144.

Veerareddy, P.R., Vemula, S.K. (2012). Formulation, evaluation and pharmacokinetics of colon targeted pulsatile system of flurbiprofen. Journal of Drug Targeting 20:703-714.

Vaskula S., Vemula, S.K., Bontha, V.K., Garrepally, P. (2012). Liquisolid compacts: An approach to enhance the dissolution rate of nimesulide. Journal of Applied Pharmaceutical Science 02(05): 115-121.

Vemula, S.K., Garrepally, P., Bontha, V.K. (2010). Development and characterization of fast disintegrating tablets of Piroxicam. Inventi Impact: Pharm Tech 1(3): 169-173.

Vemula, S.K., Bontha, V.K., Garrepally, P., Chilukala, S., Madavapeddi, A.K. (2011). Development and characterization of fast disintegrating tablets of terbinafine hydrochloride. Journal of Pharmacy Research 4(7): 22732275.

Vemula, S.K., Veerareddy, P.R. (2011). Fast disintegrating tablets of flurbiprofen: formulation and characterization. Latin American Journal of Pharmacy 3: 1135-1141.

Vemula, S.K., Veerareddy, P.R. (2013). Formulation, evaluation and pharmacokinetics of ketorolac tromethamine time-dependent colon targeted drug delivery system. Expert Opinion Drug Delivery 10: 33-45.

Vemula, S.K., Bontha, V.K. (2013). Colon targeted gaur gm compression coated tablets of flrbiprofen: formulation, development and pharmacokinetics. Bio Med Research International Article ID 287919 (Article in Press).

Vippagunta, S.R., Maul, K.A., Tallavajhala, S., Grant, D.J.W. (2002). Solid state characterization of nifedipine solid dispersions. International Journal of Pharmaceutics 236: 111-123. 